\title{
Angles
}

New Perspectives on the Anglophone World

$8 \mid 2019$

Neoliberalism in the Anglophone World

\section{The Neoliberalization of Public Spaces and the Infringement of Civil Liberties}

The Case of the Safer Cities Initiative in Los Angeles

\section{Marine Dassé}

\section{(2) OpenEdition}

\section{Journals}

Electronic version

URL: https://journals.openedition.org/angles/595

DOI: $10.4000 /$ angles.595

ISSN: 2274-2042

\section{Publisher}

Société des Anglicistes de l'Enseignement Supérieur

\section{Electronic reference}

Marine Dassé, "The Neoliberalization of Public Spaces and the Infringement of Civil Liberties", Angles [Online], 8 | 2019, Online since 01 April 2019, connection on 07 December 2022. URL: http:// journals.openedition.org/angles/595 ; DOI: https://doi.org/10.4000/angles.595

This text was automatically generated on 6 June 2022 .

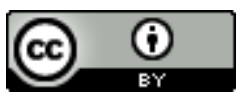

Creative Commons - Attribution 4.0 International - CC BY 4.0

https://creativecommons.org/licenses/by/4.0/ 


\section{The Neoliberalization of Public Spaces and the Infringement of Civil Liberties}

The Case of the Safer Cities Initiative in Los Angeles

\section{Marine Dassé}

"We have the largest number of millionaires, the largest number of mansions, but also the most acute poverty in the country" (L'Obs 2014). With this statement, Gary Blasi, a Law Professor at UCLA, highlights urban segregation as a particularly striking contradiction that lies at the heart of the city of Los Angeles. Wealthy neighborhoods, such as Beverly Hills, are famed for their luxurious villas and expensive hotels, yet they stand only a few miles away from one of the poorest and most dangerous areas of the nation: Skid Row, which concentrates the highest number of homeless people in the country in a very confined area of the city. For homeless people, enjoying daily access to public space to perform life-sustaining activities is a necessary condition for their survival. However, several anti-homeless laws have been passed in Los Angeles in recent decades. In 2006, the municipality implemented a program called the Safer Cities Initiative (SCI) to secure the streets. Its primary goal was to eradicate misdemeanors such as sleeping or urinating in public.

2 The publicness of an urban space - the state of a place being public - is open to interpretation. Indeed, the concept of public space is both a spatial and temporal construct, dependent on what one studies. In several papers, cultural geographer Don Mitchell has shown how rights over public spaces are not universal, they have been acquired through social struggle (Mitchell 2003). Public spaces are shaped by complex norms, and their emergence or decline is in constant evolution depending on their spatial and temporal setting. In other words, if some people can walk in some areas and not others, it is not a natural occurrence, but rather a result from specific, normative policies.

3 In this paper, the term "public space" will be understood as an urban, public area that can be accessed by anybody regardless of their social class, race, age or gender. 
However, these components affect the way individuals use public spaces. Class, race, gender and age play a tremendous role in the frequency and motives for using a public space. For instance, research has shown that young girls are discouraged from exploring their environment from a very early age (Franck and Paxson 1989: 127). If the presence of homeless people in public spaces is of tremendous importance, it is because being visible to the non-homeless population prompts the following questions: to whom should public spaces belong? What actions should be allowed in public spaces? Most importantly, is it legitimate for cities and courts to make decisions regarding the use of public spaces?

4 Local authorities have argued that safety was the primary concern for initiating the Safer Cities Initiative. However, one may question the underlying reasons behind a policy excluding homeless people from an area they have massively occupied for decades. To what extent does a program such as the Safer Cities Initiative represent new incentives to put neoliberal policies into practice in public spaces and underpin the development of neoliberal ideals? This desire to "clean up the street" results from an evolution that started in the 1980s (Brenner and Theodore 2002; Jamie Peck 2002). In recent years, anti-homeless laws have multiplied. Several questions arise from recent anti-homeless initiatives such as SCI. How can neoliberalism, as a political and economic concept, be applied to public spaces? To what extent have they become "neoliberalized"? Perhaps most importantly, to what extent does it normalize the criminalization of poverty?

5 Although the SCI has been largely covered in the local press, especially in the Los Angeles Times, it has rarely been linked with public spaces or neoliberalism. For instance, the book Down, Out and Under Arrest: Policing and Everyday Life in Skid Row by sociologist Forrest Stuart deals with Skid Row, but rarely mentions the term "public space" and practically never analyzes its link with neoliberal policies (May and Cloke 2014: 896). Similarly, in an article entitled "Spillover of the Private City: BIDs as a Pivot of Social Control in Downtown Los Angeles", German geographers Nadine Marquardt and Henning Füller offer a fascinating analysis of the close relations between publicprivate partnerships and the municipality in their attempts to control the homeless population (Marquardt and Füller 2012), but they do not explore how this type of social control originated in neoliberal principles. This article seeks to fill this gap, providing new insights in the SCI's social consequences. More particularly, it aims at shedding light on the relationship between securing the street and the criminalization of poverty, as well as demonstrating the intrinsic link with neoliberal doctrine (Peck and Tickell 2002: 391).

6 This paper shall proceed in three parts: I will firstly provide a theoretical framework to explain the extent to which securing the street can be connected to neoliberal urbanism. I will then analyze the Safer Cities Initiative in terms of socio-spatial exclusion. Finally, I will explore its impacts on civil liberties and human rights.

7 This empirically-informed paper rests on the use of several methods, primarily observant participation. From September 2013 to June 2014, I conducted ground-level research on privatization and neoliberalization in Los Angeles, focusing mainly on newspaper archives, specialized websites, and interviews. While based in California, I went to Skid Row once a month for 10 months with a group of volunteers to distribute hygiene kits and to best understand and report on the residents' daily lives and struggles. In addition, I conducted a series of interviews with local urban actors who 
were involved with the Skid Row residents at the time when the program was being implemented - among whom local activist General Jeff, also known as the "unelected mayor of Skid Row". A sample of those interviewed include Police Officer Giddens from the Los Angeles Police Department (LAPD). The interviews, ranging from 20 to 120 minutes in length, were conducted in person and the interviewees were asked several open-ended questions. Their responses were all transcribed and analyzed. On top of reports, press releases and other academic sources, the year-long evaluation of the Safer City Initiative undertaken by Gary Blasi proved particularly useful, as his research team recalculated and refuted all of LAPD's statistics on the supposed crime reduction brought about by SCI.

\section{Theoretical Framework: Homelessness in Neoliberal Cities}

8 Neoliberalism usually refers to an economic concept advocating the promotion of free markets and the reduction of state intervention. Geographer David Harvey defines it as

a theory of political economic practices that proposes that human well-being can best be advanced by liberating individual entrepreneurial freedoms and skills within an institutional framework characterized by strong private property rights, free markets and free trade (Harvey 2005)

\section{Neoliberalism: A versatile Term with Numerous Ramifications}

Geographers Jamie Peck and Adam Tickell divide neoliberalism in three main phases. The "proto neoliberalism" of the postwar period was succeeded by the "roll-back" phase of the 1980s, a "destructive moment," when the social rights and protections established after the Second World War were dissolved. However, since the 1990s,

the agenda has gradually moved from one preoccupied with the active destruction and discreditation of Keynesian-welfarist and social collectivist institutions (broadly defined) to one focused on the purposeful construction and consolidation of neoliberalized state forms, modes of governance, and regulatory relations (Peck, Tickell 2002: 384)

This marked the beginning of the "roll-out" period in the 1990s, which can be considered as an "evolutionary reconstitution of the neoliberal project in response to its own immanent contradictions and crisis tendencies neoliberal strategies". As a result, city space became "a purified arena for capitalist growth, commodification, and market discipline [and] remained the dominant political project for municipal governments throughout the world economy" (Brenner and Theodore 2002).

11 It should be noted that substantial theoretical differences exist. Marxist thinker David Harvey considers neoliberalism as an ideological, hegemonic project aimed at transferring wealth and power from the poor to the rich. Since the Great Depression, the American economy has been reorganized through massive suburbanization while new markets as well as major innovations in transport and communication technologies have emerged. These were necessary conditions for capitalist expansion to occur. According to him, capitalism constantly seeks out new spaces so that it can keep growing. These "spatial fixes" reflect the "intrinsic need of capital to spread out over space in order to overcome its inherent crises of overaccumulation" (Charney). 
Peck and Tickell also draw on Michel Foucault's work and consider neoliberalism as a process and a form of governmentality.

In the light of these considerations, neoliberalism can be envisioned quite differently depending on the aspects highlighted by different approaches. Although this would go beyond the scope of this paper, the case study presented here reveals how these analyses proved useful to understand the predominance of neoliberal ideology. On the one hand, Harvey's work helps understand intricate power relations in the city. On the other, Peck and Tickell help unfold the dynamics leading to the establishment of neoliberalism as a dominant doctrine. This account of history is necessary when studying the shaping of specific urban decisions that bolstered neoliberal policies. Indeed, these authors help understand to what extent the municipality, as well as other public entities such as the Police and judicial courts, are involved in instantiating local policies that reinforce neoliberal ideology. Neoliberalism is not just a matter of political and economic theory. It has concrete, urban implications with dramatic consequences on the most destitute individuals living in the city.

\section{Budget Cuts and their Consequences}

13 In that regard, Peck and Tickell's theory is also useful to understand how the "spacialization" of poverty in Skid Row resulted from Reagan's "roll back" neoliberalism, how it helped prepare Los Angeles to more easily introduce the "roll out" phase, and ultimately SCI.

In the 1980s, the reorganization of welfare spending (deinstitutionalization) coupled with economic restructuring (deindustrialization) paved the way for homelessness (Wolch et al. 1988). Principles of deregulation and privatization were applied to many sectors. The Reagan administration cut public spending while encouraging free enterprise, stimulating competition and innovation. The idea of individual accountability led to drastic cuts in welfare state budgets. Under the Reagan presidency, many federal programs were transferred to state and local governments, while the non-profit sector was gradually called upon to replace federal government intervention, privatizing social aid (Wolch et al. 1988).

Some examples include the Housing and Urban Development budget. Under Reagan, $\$ 18.2$ billion was allocated to assisted housing, compared to $\$ 30.9$ billion under the Carter administration: between 1980 and 1988, the HUD budget was cut down by more than 50\%. In 1981, the Reagan administration also passed the Omnibus Budget Reconciliation Act, which notably provided an increase in rent for housing tenants. Cardiss Colin, chairwoman of the House Government Operations Subcommittee on Manpower and Housing, warned that it would put more homeless people on the street (Biles 2011: 251-6).

Between 1982 and 1985, the administration cut the annual amount of federal funding for the poor by $\$ 57$ billion. Between 1980 and 1988, the proportion of federal housing budget allocated for building new public housing units fell from $80 \%$ to $4 \%$ (Stuart 2016: 58-59). This shift toward greater wealth for some and declining aid for others corresponds to what Harvey has called "the restoration of economic power of high social classes" (Harvey 2005: 26).

17 In the same vein, the government decided to lower federal aid to cities, meaning that they had to find other sources of investment. Local governments were, and are now, 
not only "expected to ally with business to improve their plight, they are also increasingly expected to behave as businesses as well." The consequences of the Reagan administration's "trickle-down economics" on the urban fabric were immense, and it comes as no surprise that homelessness intensified in the 1980s (Hackworth 2006: 26, 285).

\section{The Neoliberalization of Public Spaces} Georgetown University, "once domains of private property began to dominate the cultural and physical landscape, vagrancy began to be seen as a threat to capitalism" (Amster 2004: 110). As a result, one of the direct consequences of the neoliberalization of urban spaces has been the emergence of a strong incentive to "clean up the streets," enabling fewer people to access these once-inclusive areas. Urban public spaces have become commodified entities that serve private businesses' interests. The predominance of economic competition shows how entrenched neoliberal policies have become in urban settings.

\section{A Punitive Turn}

The neoliberalization of public spaces can be defined as a set of policies designed to attract more capital to alleviate cuts in local budgets. Finding strategies to attract more tourists and businesses has become a major characteristic of these policies, and this new approach to urban development has normalized market logic. In response to the growing and ongoing pressure of new entrepreneurial norms, cities must be more competitive and find new investment opportunities. For example, public-private partnerships are now a commonly-used tool in order to provide services to residents. competition to attract new urban actors and investors to develop growth. More than ever, urban spaces are a central element of a city and showcase its primary image. These spaces need to look appealing to attract more capital. The emphasis on cleanliness as the key strategy to revitalize neighborhoods has entailed getting rid of the "undesirables" - panhandlers, prostitutes, the mentally ill and homeless people. These "undesirables", who do not fit the expected profile and are perceived as impediments to downtown revitalization, are removed from zones designed for economic development. Homeless people in particular are viewed as obstacles to the attractivity of public spaces.

competition between cities, have shaped cities into entrepreneurial entities. SCI reflects the municipality's desire to push the undesirables further away from places of interest, and how interurban competition has led public powers to sanitize urban areas. In an illustration of the pervasiveness of neoliberalism, public places are perceived as investment opportunities, and cities feel compelled to defend their marketing images.

In the words of Randall Amster, Director of the Program on Justice and Peace at The Safer Cities Initiative and other anti-homeless policies also reflect a "punitive turn" in criminal justice. Hyper-punitive policies can best be understood by looking at what French sociologist Loïc Wacquant called the "crisis of the welfare state." 
Wacquant argues it took the form of "the irruption of the penal state in America, and its practical and ideological repercussions upon the other societies subjected to the 'reforms' fostered by neoliberalism" (Wacquant, 2009: xiii).

At the end of the 1970s, the punitive model became a "managerial model" whose goal was to "make a profit" (Body-Gendrot 1998: 43). At the turn of the 1980s, a new punitive model emerged: rehabilitation and reintegration were supplanted by repression and exclusion. The goal of this new approach was to "handle flows and contain costs by carefully eluding the question of the causes and consequences of hyper-incarceration, and [to] turn away from the social fate of the inmate once his sentence has been served." Statistics clearly show this shift in penal policy. The index of "punitiveness" rose from 21 prisoners per one thousand crimes in 1975 to 37 in 1985 and 75 in 1995, before jumping to 113 in 2000. In addition, by comparing the numbers of prisoners to the number of violent crimes committed, statistics also show that the justice system mostly sentences petty delinquents (Wacquant 2009: 127-8, 145).

In the last four decades, Wacquant notes there has been a clear shift in the role of the State:

a protective (semi) welfare state [was gradually replaced] by a disciplinary state mating the stinging goad of workfare with the dull hammer of prison fare, for which the close monitoring and the punitive containment of derelict categories stand in for social policy toward the dispossessed (Wacquant 2009: 79)

The city of Los Angeles can be regarded as an especially fertile ground for neoliberal policies as the Safer City Initiative aptly illustrates both the neoliberalization of the city and punitive policies. Even if the official policy of the program was to "secure the street" and not to "clean it up," it did remove the "undesirables."

\section{Social Exclusion, Spatial Exclusion: The Safer Cities Initiative in Los Angeles}

Before analyzing the program's implementation and its consequences, one must understand how the spatialization of Skid Row shapes social exclusion.

\section{Skid Row, Los Angeles}

Skid Row is a fifty-block area where thousands of people live in extreme poverty in a specific perimeter. Crime rates there are among the highest in Los Angeles and it is also the most impoverished area in the city (Ghorra-Gobin 2002: 250). Many inhabitants live on the sidewalk and hundreds of tents are the homes of mentally disabled individuals, veterans and undocumented families. It is the largest homeless community in the United States: between 11,000 and 12,000 people sleep there each night (Gerry 2007: 239-51). Anyone walking through Skid Row can observe the blatant human misery. One does not need to be a psychiatrist to see that a great number of mentally-ill residents live on the streets of Skid Row. When I went there to distribute hygiene kits, people would run up to my group and rip the kits right out of our hands. I met numerous severely mentally-disabled individuals and illegal South- American families with children, some only toddlers. I also met a veteran who quickly became homeless after coming back from Afghanistan and losing his job, with no family support. There were also many people in wheelchairs. 
Figure 1. Los Angeles. June 2014.

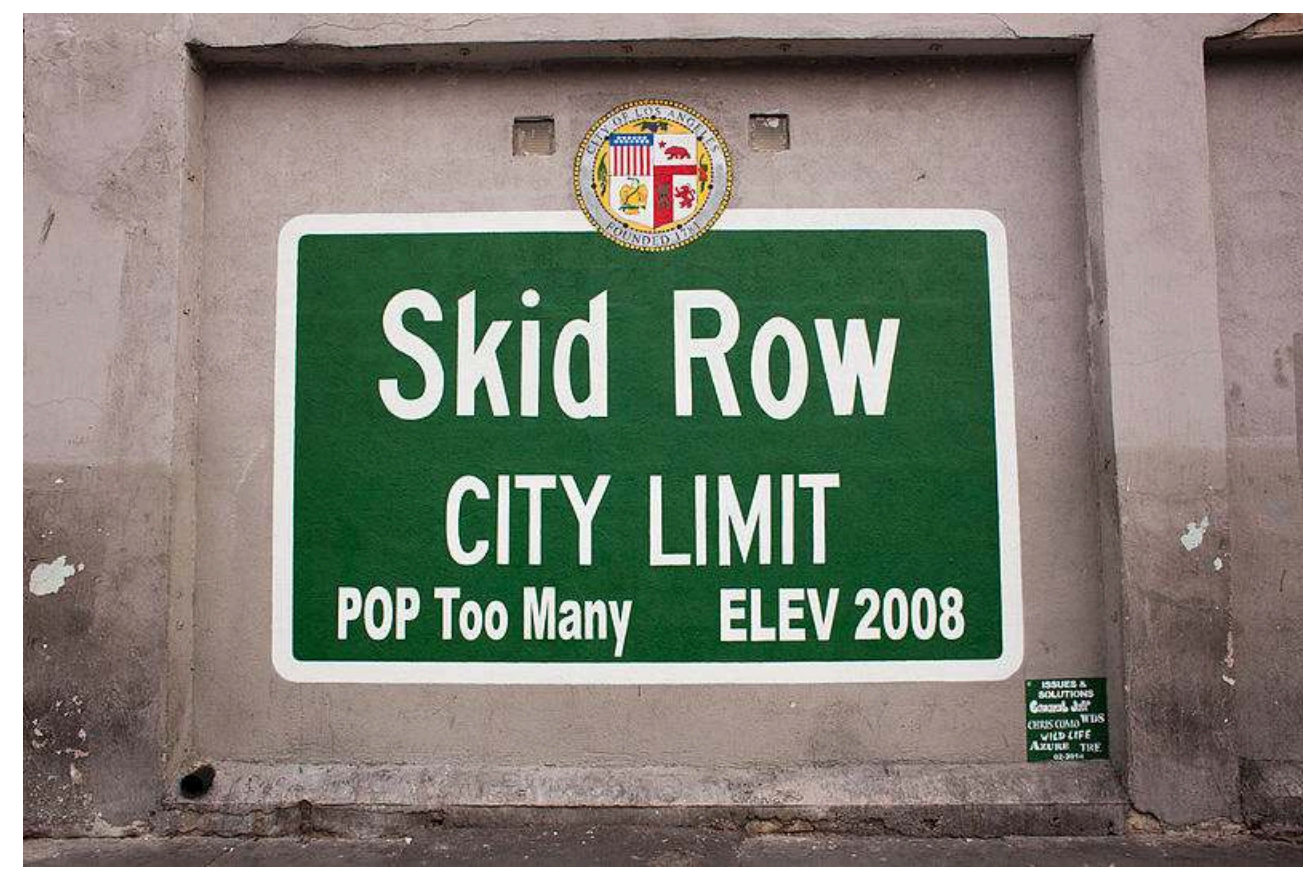

Source: picture taken by the author.

This urban segregation is a result of a "containment policy" that started in the 1970s when the municipality decided to concentrate all forms of extreme poverty in one designated area. Historian Mike Davis considers that official policy has transformed Skid Row into one of the "most dangerous ten square blocks in the world" (Davis 1990: 232). On top of that, Downtown Los Angeles has a very high concentration of lowskilled employment. After losing manufacturing jobs, the district has surged in "internationally oriented producer services and finance capital". According to geographers Robin Law and Jennifer R. Wolch, the rise of homelessness in Los Angeles occurred through the globalization of the urban economy of the city-region (Law and Wolch 1991: 129).

In the 1960s and 1970s, most residents of Skid Row were mainly working poor. Following a logic of individual responsibility as opposed to collective responsibility, the Reagan administration initiated several laws that led to a dramatic increase in poverty. Among others, it severely restricted federal aid for housing low-income people (Scott 2014: 869). In 2006, by the time SCI was implemented, the average rent in Los Angeles was 1750 dollars a month, 82\% more than ten years earlier (Reese et al. 2010: 315). California has experienced a lack of residential construction in comparison with the job and population growth. This has led to increased housing prices driven up by wealthier residents (Khouri 2017). As a consequence, rents have risen steadily. Moreover, between January 2005 and October 2006, Los Angeles lost 9,000 rent-controlled apartments (Cleeland 2006). Such an increase undoubtedly gentrifies the neighborhood, pushing low-income residents further away from the area.

Social exclusion has been reinforced through the spatial organization of the city itself, since shelters, as well as aid which benefit homeless people, are only located inside the most impoverished urban communities, far from residential and commercial areas (Von Mahs 2015: 70). Therefore, the concentration of misery is the result of specific 
political decisions. The history of Skid Row shows that it spatially segregated a population that was already isolated socially. Such policies, as well as anti-homeless laws, are symbolic of the pervasiveness of the neoliberal doctrine. Peck and Tickell rightly point out that

zones of deeply impacted poverty and social exclusion may have been no-go areas for neoliberals during the 1980s, in its rollout guise, neoliberalism is increasingly penetrating these very places, animated by a set of concerns related to crime, worklessness, welfare dependency and social breakdown (Peck and Tickell 2002: 395)

31 This is particularly the case for Los Angeles. In the 1990s, Skid Row and the inner city started to attract the interest of developers and businesses. The "containment policy" was meant to appease them. But in the 2000s, the municipality had to find other solutions.

\section{A Strategy for Revitalization}

The neoliberal rhetoric implies that it is in society's best interest that public resources should be used to facilitate and protect private investors. It is particularly striking in the case of Los Angeles where the business community is quite powerful and has been heavily involved in displacing homeless people through the use of private security forces. General Jeff, commonly referred to as the "unelected mayor of Skid Row", has been a local social activist for the last twenty years and remembers when the antihomeless policy was launched. He explained the underlying reasons behind the project: "the problem with this sales pitch is no matter where you go in Los Angeles, right in the middle of the donut is the hole: right in the middle of anything in LA is Skid Row" (General Jeff 2014). Indeed, Skid Row is located in Downtown Los Angeles and can be considered as an obstacle to revitalizing the city. Whereas the rest of the city looks attractive, Skid Row is discordant. This perception is also predominantly held by the business sector. Carol Schatz, CEO of the Downtown Association of Local Business declared: "Investment dollars will not flow to neighborhoods that suffer from crumbling sidewalks and pothole-filled streets" (Los Angeles 2020 Commission Report 2013).

In 2003, the newly-appointed LAPD Chief William Bratton and the mayor of Los Angeles decided to revitalize the city and suddenly enforce section 41.18(d) of the municipal code which provided that "[n]o person shall sit, lie or sleep in or upon any street, sidewalk or other public way except during parades and upon benches" (Gerry 2007: 241). Overnight, homeless people were banned from the streets and camping was deemed illegal. Even if this had been in the municipal code since 1968, this section was rarely applied. The police carried out mass arrests of those who committed minor offenses such as jaywalking, public drinking or loitering. This resulted in police harassment towards homeless people as well as the repeated use of extremely repressive methods.

Homeless people fell foul of the new policy. Hundreds of citations were given for misdemeanors such as sitting on the sidewalk or urinating in public. Those refusing to cooperate faced $\$ 1,000$ fines and six months' imprisonment (Gerry 2007: 241-2). For a homeless person living on public assistance and earning little more than $\$ 220$ dollars a month, paying such fines entailed not being able to meet their basic needs such as feeding themselves (Stewart 2003). 

of Los Angeles in the name of Jones and Robert Lee Purrie who lost all their belongings during an arrest. The judges did not consider that the new policy had targeted homeless individuals, but rather their behavior. The plaintiffs lost their first trial and appealed to the Ninth Circuit Court of Appeal. The Court of Appeal ruled in favor of ACLU and homeless people, and against the city of Los Angeles. The Court remarked that "human beings are biologically compelled to rest, whether by sitting, lying, or sleeping" (ACLU 2016). Given that the number of beds was limited in Los Angeles, the Court also stated that if "the only alternative to violating an ordinance is death, its enforcement cannot be anything but cruel and unusual punishment," (Gerry 2007:250) which is prohibited by the Eighth Amendment to the Constitution. Jones v. City of Los Angeles (2006) represents a historic judicial decision stating that "The Eighth Amendment prohibits the City from punishing involuntary sitting, lying, or sleeping on public sidewalks that is an unavoidable consequence of being human and homeless without shelter in the City of Los Angeles." In the final decision, judges considered that "section $41.18(\mathrm{~d})$ is one of the most restrictive municipal laws regulating public spaces in the United States".

Eventually, an agreement was reached between both parties. The homeless were allowed to sleep on the street but could not stay by business entrances during operating hours. Such anti-homeless laws, as well as the SCI, which I analyze further down, were made possible by the emergence of the so-called "broken-window theory".

\section{The "Broken-Window Theory" and its Consequences}

Also known as "zero-tolerance policy," the broken-window theory refers to a strategy to fight urban crime which emerged in New York City in the 1990s. This theory considers that physical decay and incivilities (e.g. graffiti or public urination) may incite other people to do the same. By suppressing "quality of life offenses" - all sorts of minor offenses such as drinking, sleeping, jaywalking, begging or littering in public - you will prevent more serious crimes from happening. The broken window theory was designed by conservative political scientists James Q. Wilson and George Kelling, the former Chief of Police of Kansas City who became a senior fellow at the Manhattan Institute, a neoliberal think tank. They were paid half a million dollars to help the city of Los Angeles design the SCI (Blasi and UCLA 2007: 5).

However, the "broken-window theory" is not a fully coherent concept and was not expounded in an academic journal, but rather in a cultural magazine, the Atlantic Monthly. Most importantly, it has never received any empirical verification (Wacquant 2009: 267). Published as a nine-page article lacking scientific grounding, this popular theory nonetheless became the main justification for harassing non-standard individuals, or "fixing the poor" in the words of anthropologist Forrest Stuart. It should come as no surprise that the broken-window theory sparked controversy. Scholars and sociologists have pointed out its multiple inconsistencies; Christian Parenti referred to it as "science of kicking ass;" and sociologist Loïc Wacquant wisely observed that "rapists and killers don't head for another town when they see that graffiti is disappearing from the subway" (Wacquant 2009).

Three years after the Jones $v$. The City of Los Angeles decision stipulating that homeless people could not be banned from the streets, the city launched SCI, which represented 
a "softer version" of the previous policy. SCI's official primary goal was to make the area safer through 80 additional law-enforcement officers, making it the densest concentration of standing police forces in the country (Stuart 2016: 6). It continued to target quality of life offenses and the core idea remained the same: policemen could arrest any individual (mostly homeless people) for any type of minor offense. Twelve thousand citations were given in 2007, between 48 and 69 times the rate at which such citations are issued citywide (Blasi and UCLA 2007: 5).

General Jeff harshly condemned the LAPD's harassment strategies:

It's bullying tactics but on paper, it's the "broken-window theory" [ ...] The officers were targeting low-level crime: jay walking, public intoxication, urination. They would beat people up, arrest people for nothing and that for a whole fifty blocks.

That's idiotic but that's what the business sector wanted... (General Jeff 2014)

With SCI, the police continued to harshly condemn minor infractions and harass "the undesirables." Unsurprisingly, it led to the increasing incarceration of homeless people who could not afford to pay the fines (Marquardt and Fuller 2012: 162). Countless homeless people were arrested for insignificant misdemeanors and repression was taken to extremes. One person reported being issued a littering ticket for simply flicking his cigarette ash into the breeze (Stuart 2016:5).

On top of harassing people for insignificant misdemeanors, the program was problematic for several reasons. Contrary to its official policy aim, it failed to reduce crime. The LAPD claimed that crime had dropped by $35 \%$ after the first 8 months of $\mathrm{SCI}$, as compared to $5 \%$ observed in the eight months preceding it (LAPD 2007). Blasi and his team, who conducted a one-year research to evaluate the impacts of the project, refuted such findings. They analyzed all the data again and found that criminality fell in the Skid Row area, without being able to prove causality. Firstly, special forces made few arrests for serious and violent crime (e.g. murder, rape), and most violent crime rates declined more outside skid Row than within its limits. Secondly, given the greater density of officers on patrol compared to the rest of the city, it should come as no surprise that the crime rate fell. Thirdly, as numerous residents left the area because of police harassment and others were behind bars, it is legitimate to assume that it automatically led to a significant drop in the number of crimes reported (Blasi and UCLA 2007: 44). Despite the LAPD's claims, the crime reduction cannot be attributed to SCI.

Ultimately, the multiplication of punitive measures for insignificant actions that neither pose a real threat nor harm anyone is both unfair and inefficient to fight urban crime. Rather than contributing to eradicating poverty, such programs only displace and ignore misery.

\section{“People need shelters, not jail cells" (Los Angeles Times 1987)}

Focusing exclusively on minor infractions such as public urination can be regarded as an interventionist mode of social control. The goal of such programs is to normalize the behavior of individuals considered as "undesirables" and force them to adhere to hegemonic expectations and norms: only the individuals deemed "desirable" may remain in public spaces; the others are to be displaced or incarcerated. this measure is clearly applied against people who are unwanted in certain spaces. As 
cultural anthropologist Joanne Passaro has noted, "public space has come to be seen not as the last frontier of freedom, but rather as a frontline in battles over social control" (Passaro 1996: 82).

Figure 2. Public bans. Skid Row. Los Angeles. June 2014.

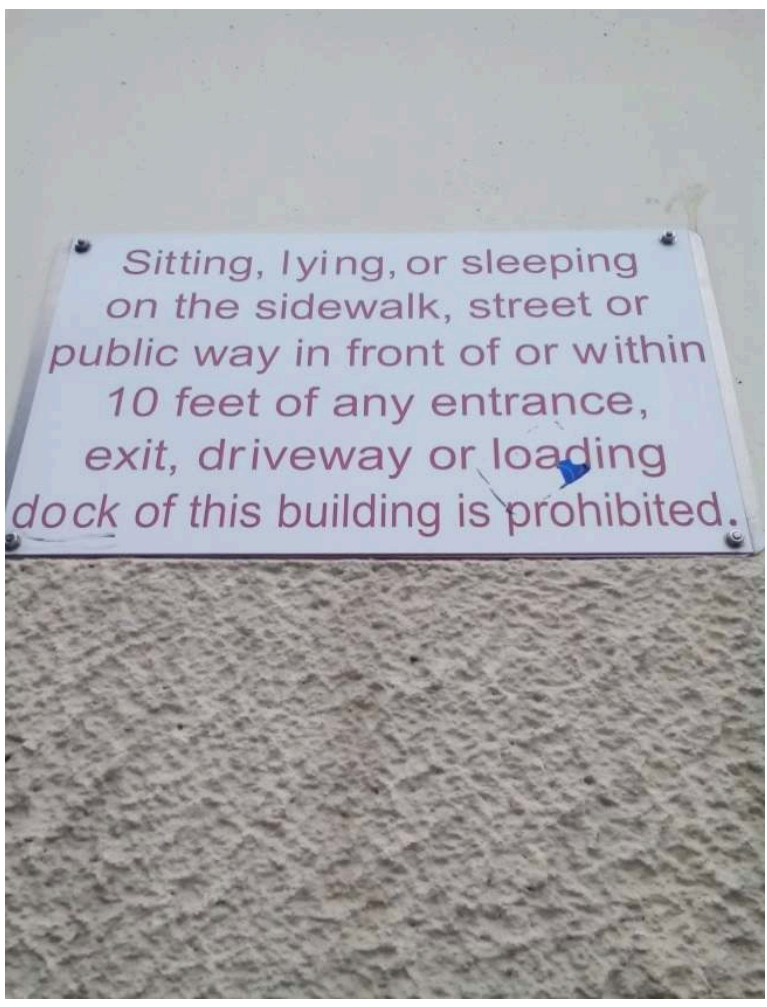

Source: picture taken by the author.

These anti-homeless laws reflect a discriminatory and ineffective approach to poverty, whose real goal seems to be making way for gentrification. They not only fail to fight serious and violent crimes; they also reinforce the processes through which neoliberalism exacerbates social differences and criminalize poverty.

According to Don Mitchell, these policies also redefine the very concept of citizenship: "These laws have a goal - perhaps not explicit but clear nonetheless - the redefinition of public rights so that only the housed may have access to them" (Mitchell 2012: 171). Therefore, they work as a social filter where only those who respect the current norms and standards are deemed acceptable in public spaces.

\section{Civil Liberties and Human Rights}

The ideal of unfettered capitalism and its implementation in neoliberal policies had intense repercussions on urban areas, where it fostered uneven spatial development. Whereas some areas grew even wealthier, the poor neighborhoods went from bad to worse. 


\section{Neoliberal Urbanism}

This aims at allowing the public spaces of a city to become viable sites for capital accumulation so that the urban core can be reinvigorated. Ideologically, policies targeting homeless people reflect the belief that individuals should be held responsible for their own condition and actions. Geographers Steve Herbert and Elisabeth Brown suggest that neoliberalism “increases the degree of 'responsibilization' devolved to local areas and individual citizens/consumers. In the process, notions of a collective public wither, as does the degree of shared obligation to the disadvantaged members of that collective" (Herbert and Brown 2006: 772). Indeed, neoliberalism portends that the emphasis should be put on the individual while rendering local authorities unaccountable.

Anti-homeless laws and policies revolve around this understanding of laissez-faire individualism that reached its height when homeless people started to be considered as deserving their condition. Following the neoliberal logic of minimal state intervention and the individual's responsibility for itself, this type of policy conveys the belief that urban poverty finds its roots in an individual's bad decision-making or simple lack of willpower. Instead of being helped, poor people need guidance and treatment. These policies serve as a means to justify discrimination and criminalize poverty.

51 General Jeff is aware of this endeavor to promote a positive image of the city and to secure urban spaces for new investments: "A lot of people have bought into the 'smoke and mirrors' campaign, the marketing hype: they thought great they're cleaning up Skid Row, it is only going to be a matter of time and the property values are gonna go up..."(General Jeff 2014). His observation concurs with statements by the local business community:

Downtown Los Angeles is on the cusp of an urban renaissance. Our fondest dreams of Smart Growth, with workers living in affordable, high-density buildings near transit, employment, cultural, and retail centers may finally become a reality in Downtown. However, this renaissance is threatened every day by street encampments, drug deals, overdoses, and panhandlers (Blasi and UCLA 2007: 10).

Restructuring the spatial organization of the city so it can serve business interests and ultimately help to enhance profits, has become the official priority. The goal is to attract a homogeneous middle class, made up of clean, passive consumers who actively contribute towards the local economy. Achieving this requires mobilizing the entrepreneurial identity of the city, which does not feature thousands of people sleeping on a sidewalk.

General Jeff also explained that the municipality's primary goal is to support commercial interests rather than to create public spaces that would be as inclusive as possible: "The business sector is trying to project this image of a newly-revitalized downtown around the world, so that international tourism and commerce can increase, and businesses can benefit from the additional revenue" (General Jeff 2014). For the municipality, the primary concern is protecting downtown land values and serving local commercial interests, and more precisely, those of public-private partnerships. On top of wasting public money and being incoherent, SCI and its ilk pose a real threat to civil liberties. 


\section{Neoliberalism and the Right to the City}

Marxist thinker Henri Lefebvre shed light on the direct link between urban planning and sociology. He showed that the way a city is laid out can serve as a tool of social control by segregating individuals. To counter this socio-spatial segregation, he coined the concept of the "Right to the City" (in French: "droit à la ville"). Despite its ambiguity, this expression is helpful to understand that even though the street is commonly thought of as a public space that anybody can access, not everyone is equally welcome. Who has the right to the city of Los Angeles in the early $21^{\text {st }}$ century? The answer appears to be only those who comply with current standards and can afford a roof over their heads.

Anti-homeless policies pose problems for several reasons. Firstly, they seek to cure the symptoms of poverty instead of addressing its causes. Not only does SCI oversimplify the concept of criminality, it conveys a paternalistic approach to poverty. Some of the SCI lieutenant's words illustrate it well: "Our job is to help them to make the right choice. If they don't want to make the right choices to get better, to move up and out of here, then we have to step in". Another officer made a similar comparison: "Ultimately, it's our job to set the standard. There is really nobody else who is doing it. When you look out on the streets, most people have pretty much communicated to us that they aren't willing to make good choices in their lives" (Stuart 2007: 108). During a personal interview, officer Giddens took the comparison further and associated shelters with a family:

They [shelters] have certain hours of operation just like a parent's house, they [homeless individuals] don't want to conform. People don't want to take advantage of them [...] There are lots of resources, we can house a lot of the population, there are $50 \%$ of them utilized (Giddens 2014)

However, this figure is highly inaccurate. Gary Blasi's report states that "The median number of actually available shelter beds in Skid Row has been four beds, at a time when the LAPD was counting about 1,000 homeless people living on the sidewalks each night" (Blasi and UCLA 2007: 5).

Even more worrisome, one of the policemen tried to dissuade homeless people from using the provided facilities if they weren't ready to make a real "change" in their "lifestyle." He went in front of a shelter and used speakers to broadcast the following message:

There are people trying to get help here in the mission. If you want to get help, you're welcome to be here. If not, if you want to poison yourselves and engage in criminal activity, you're going to have to leave the block. I will not let you interfere with their positive change. If you decide you want to get better, you can come back (Stuart 2016)

His statement illustrates the neoliberal logic and how the local authorities make a stark distinction between the "deserving poor" and "undeserving poor." This binary perspective sends a clear message to the residents: those lacking the willpower are not welcome in Skid Row; worse, they do not deserve help.

Secondly, anti-homeless policies question the right to be different or to have an alternative lifestyle. The repression or prevention of serious crime no longer seems to be the priority of the police. Instead, their role is conceived of as guiding and educating individuals who are considered ill-adapted, if not abnormal. The police and the municipality have set new normative parameters for an "acceptable" public. The 
systematic exclusion of "undesirables" embodies this desire to impose dominant norms. In urban spaces such as Skid Row, only people who respect the new standards are allowed. Decisions targeting homeless people are representative of the growing belief that those at the bottom of the social hierarchy should not be helped but rather disciplined.

These policies can only generate more resentment toward state institutions as they fail to tackle the real causes of poverty. Indeed, the municipality and the police can be held responsible for their respective proactive roles in supporting some users' use of public space over others and, by extension, directly favoring a specific social class over another. This new way to govern social relations in the inner city is aimed at attracting and maintaining a new affluent upper middle class that is actively consumerist. Forrest Stuart considers that this strategy of "social cleansing" is not about "disorderly places or quality of life" but about "policing poor people in poor places" (Stuart 2016). Finally, and maybe most importantly, these policies pose direct threats to democracy.

\section{Public Spaces and Democracy}

61 If citizenship goes beyond voting, then streets play a vital role within democracy, and having a common space available to all is essential. Even in the Internet era where most citizens can express themselves freely online, physical spaces have not become irrelevant, since the very concept of democracy requires access for everyone to a neutral, free and accessible space. The existence of an inclusive space where any group can express itself is of paramount importance to democracy. Under a tyrannical regime, demonstrations in public spaces are generally forbidden, demonstrating that public spaces possess a highly symbolic function. Public spaces can thus be considered as democratic linchpins and should be understood as forums for civil expression.

According to cultural geographer Don Mitchell, "the regulation of public space necessarily regulates the nature of public debate: the sorts of actions that can be considered legitimate, the role of various groups as members of the legitimate public and so forth" (Mitchell 2003: 182). By regulating behavior considered as "acceptable," the authorities also regulate who should be allowed in public spaces. Mitchell described how anti-homeless laws aim at creating a "world in which a whole class of people simply cannot be, entirely because they have no place to be." By criminalizing insignificant misdemeanors that pose no threat to others, anti-homeless laws endanger core principles of tolerance rooted in democratic societies: they question individuals' and groups' very right to exist.

63 Further to the importance of maintaining a public space that is accessible to everyone regardless of their social status, respecting civil liberties for all citizens is a key component of a democratic society. Civil liberties, like public spaces, are a social construct. They have often been legally defined, but result from collective action. They are not a natural occurrence, and if they have been socially constructed, they can also be "deconstructed" as it is the case with the SCI. In the light of rampant neoliberalism in advanced capitalist societies, the legacy of civil liberties remains extremely fragile in America in the early $21^{\text {st }}$ century. Jim Crow laws, which enforced racial segregation in the Southern US, represent a relevant example in recent history that shows how freely accessible public spaces should not be taken for granted. 
64 My case study only illustrates a more general tendency towards exclusion. Multiple laws passed across the US against panhandling and the like clearly target poor people. In Indianapolis, homeless people were even temporarily prohibited from voting. In some shelters, homeless people must wear orange outfits, similar to prison garb. In other cities, such as Atlanta, one cannot lawfully cross a parking lot unless one's car is parked within it (Wyly \& Hammel 2003: 10-11). Harassing homeless people for their condition rather than for their actions has become increasingly ubiquitous. These policies threaten democracy as they inevitably entail punishment practices that not only intensify social divisions rooted in class and race, but also entail the criminalization of poverty.

\section{Conclusion}

This paper has explored the dramatic importance of public spaces in contemporary societies in the context of pervasive neoliberalism. Entrepreneurial cities which prioritize economic profit increasingly remove "undesirables" (i.e. homeless people and other people perceived as problems) who tarnish the image of their public spaces.

The Safer Cities Initiative reflects a punitive turn that started in the 1970 s and can be analyzed as a paradigm of neoliberalization through exclusion. Poor people are being evicted so that urban spaces can look attractive in order to gain capital. Police harassment fails to reduce criminality and further demonstrates the ways in which spatial exclusion and social exclusion mutually reinforce each other. Public spaces have become a commodity, serving the interests of the privileged few. According to geographer Myron Levine:

Urban patterns are not inevitable. Patterns of growth and decline are not simply the product of human desires (for a better life, a larger home, and a safer neighborhood) and the workings of an unfettered free market. Rather, government policies as well as the exercise of private power, play a great role in determining just which communities grow and which decline (Levine 2016: 13)

In other words, if some dilapidated neighborhoods are plagued with violence and poverty while others benefit from a brand-new infrastructure, it did not result from a natural urban cycle but from a specific social construct, initiated by specific political choices.

Envisioning a more inclusive, more accessible city is possible. Many foundations and non-profits organize events that seek to promote public spaces and reverse the trend of privatization of public spaces. In Los Angeles, CicLAvia is an open streets initiative whose goal is to make various roads and streets accessible to non-motorized vehicles such as bikes or pedestrians so that they can enjoy urban areas they normally do not have access to. CicLAvia, whose goal is to "catalyze vibrant public spaces", "engages with people to positively transform our relationship with our communities and with each other".

69 In a different vein, the Right to the City was adopted by the World Urban Forum and also elaborated to form the World Charter of the Right to the City in 2004. Associations such as the Right to the City Alliance strive to put it into practice and fight to build a better urban future. They are a national alliance of racial, economic and environmental justice organizations seeking to fight against gentrification. Be it with car-free street 
events or long-term initiatives, means exist and solutions depend on political willpower and struggles for social justice.

\section{BIBLIOGRAPHY}

ACLU. "ACLU of Southern California Wins Historic Victory in Homeless Rights Case.” 14 April 2006. https://www.aclu.org/news/aclu-southern-california-wins-historic-victory-homelessrights-case

Amster, Randall. Street People and the Contested Realms of Public Space. New York: LFB Scholarly Publishing, 2004.

Biles, Roger. The Fate of Cities: Urban America and the Federal Government. 1945-2000. Lawrence: UP of Kansas, 2011.

Blasi, Gary and The UCLA School of Law Fact Investigation Clinic. Policing Our Way Out of Homelessness? The First Year of the Safer Cities Initiative on Skid Row. Los Angeles: USC Center for Sustainable Cities, 2007. http://www.ced.berkeley.edu/downloads/pubs/faculty/ wolch_2007_report-card-policing-homelessness.pdf Body-Gendrot, Sophie. Les villes face à l'insécurité. Paris: Bayard Jeunesse, 1998. Brenner, Neil and Nik Theodore. "Cities and the Geographies of 'Actually Existing Neoliberalism"'? Antipode 34 (3) 2002: 349-79. DOI: 10.1111/1467-8330.00246.

Charney, Igal. "Spatial Fix.” In Barney Warf (ed.). Encyclopedia of Geography. Los Angeles: SAGE Publications 2010: 2639-40. DOI: 10.4135/9781412939591.

Cleeland, Nancy. “Low Pay. High Rent. Wit's End.” Los Angeles Times, 24 October 2006. http:// articles.latimes.com/2006/oct/24/local/me-apartment24

Davis, Mike. City of Quartz: Excavating the Future in Los Angeles. New York: Verso, 1990.

Franck, Karen A. and Lynn Paxson. "Women and Urban Public Space." In Irwin Altman and Ervin H. Zube (ed.). Public Places and Spaces Human Behavior and Environment (Advances in Theory and Research). Boston, MA: Springer, 1989: 121-46. DOI: 10.1007/978-1-4684-5601-1_6.

General Jeff. Interview with the author. Los Angeles, June 2014.

Gerry, Sarah. "Jones v. City of Los Angeles: A Moral Response to One City's Attempt to Criminalize. Rather than Confront. Its Homelessness Crisis." Harvard Civil Rights-Civil Liberties Law Review 42 (1) 2007: 239-251.

Hackworth, Jason. The Neoliberal City: Governance. Ideology. and Development in American Urbanism. Ithaca, NY: Cornell UP, 2006.

Harvey, David. A Brief History of Neoliberalism. Oxford: Oxford UP, 2005.

Herbert, Steve and Elizabeth Brown. "Conceptions of Space and Crime in the Punitive Neoliberal City.” Antipode 38 (4) 2006: 755-77. DOI: 10.1111/j.1467-8330.2006.00475.x. 
Khouri, Andrew. "For Tenants on the Edge. Paying the Rent Often Takes More than Half Their Income." Los Angeles Times, 3 December 2017. http://www.latimes.com/business/la-fi-risingrents-affordable-housing-20171203-story.html.

LAPD. “Chief Bratton Gives Safer Cities Update on Skid Row”. News Release, 8 June 2007. http:// lapdonline.org/june_2007/news_view/35562

Law, Robin and Jennifer R. Wolch. "Homelessness and Economic Restructuring." Urban Geography 12 (2) 1991: 105-36. DOI: 10.2747/0272-3638.12.2.105

Levine, Myron. Urban Politics: Cities and Suburbs in a Global Age. New York: Routledge, 2015.

L'Obs, “Los Angeles: Skid Row. la Cité des Anges déchus." L'Obs. 30 September 2014. https:// www.nouvelobs.com/societe/20140930.AFP7178/los-angeles-skid-row-la-cite-des-angesdechus.html.

Von Mahs, Jürgen. Down and Out in Los Angeles and Berlin: The sociospatial exclusion of homeless people. Philadephia: Temple UP, 2013.

Marquardt, Nadine and Henning Füller. "Spillover of the Private City: BIDs as a Pivot of Social Control in Downtown Los Angeles." European Urban and Regional Studies 19 (2) 2012: 153-66. DOI: 10.1177/0969776411420019.

May, Jon and Paul Cloke. "Modes of Attentiveness: Reading for Difference in Geographies of Homelessness.” Antipode 46 (4) 2014: 894-920. DOI: 10.1111/anti.12043.

Mitchell, Donald. "The Annihilation of Space by Law: The Roots and Implications of AntiHomeless Laws in the United States." Antipode 29 (3) 1997: 303-35. DOI: 10.1111/1467-8330.00048.

Mitchell, Donald. The Right to the City: Social Justice and the Fight for Public Space. New York: The Guilford Press, 2003.

New York Times, “Transcript of President's State of the Union Message to Nation”, New York Times, 27 January 1982.

Officer Giddens. Interview with the author. Los Angeles, June 2014.

Passaro, Joanne. The Unequal Homeless: Men on the Streets. Women in Their Place. New York: Routledge, 1996.

Peck, Jamie and Adam Tickell. “Neoliberalizing Space.” Antipode 34 (3) 2002: 380-404. DOI: 10.1111/1467-8330.00247.

Reese, Ellen, Geoffrey Deverteuil and Leanne Thach. “'Weak-Center' Gentrification and the Contradictions of Containment: Deconcentrating Poverty in Downtown Los Angeles." International Journal of Urban and Regional Research 34 (2) 2010: 310-27.

Scott, Brittany. "Is Urban Policy Making Way for the Wealthy? How a Human Rights Approach challenges the Purging of Poor Communities from US Cities?" Columbia Human Rights Law Review 45 (3) 2014: 863-895.

Stewart, Jocelyn Y. "ACLU Sues to Block Enforcement of L.A. Ordinance Against Homeless." Los Angeles Times, 20 February 2003. https://www.latimes.com/archives/la-xpm-2003-feb-20-mehomeless20-story.html

Stuart, Forrest. Down. Out. and Under Arrest: Policing and Everyday Life in Skid Row. Chicago: U. of Chicago P., 2016. 
The Planning Report, “Los Angeles 2020 Commission Report 'Time for Truth.' Highlighted by Mickey Kantor". The Planning Report, 12 February 2014. https://www.planningreport.com/ 2014/02/12/los-angeles-2020-commission-report-time-truth-highlighted-mickey-kantor.

Los Angeles Times. “Jail for the Homeless." Los Angeles Times. 1 June 1987. http:// articles.latimes.com/1987-06-01/local/me-5407_1

Wacquant, Loïc. Punishing the Poor: The Neoliberal Government of Social Insecurity. Durham: Duke UP, 2009.

Wolch, Jennifer R., Michael Dear and Andrea Akita, "Explaining Homelessness", Journal of the American Planning Association 54 (4) 1988: 443-53. DOI: 10.1080/01944368808976671.

Wyly, Elvin K. and Daniel J. Hammel. “Mapping Neoliberal American Urbanism.” In Gentrification in a Global Context: The New Urban Colonialism. Rowland Atkinson and Gary Bridge (ed.). London: Routledge, 2005: 18-38.

\section{ABSTRACTS}

Neoliberal policies have required a new way to envision urban areas. Municipalities try to bolster their image in order to attract new capital, which entails getting rid of the undesirables (the homeless and other people perceived as problems) who tarnish the image of their public spaces. This article explores the socio-political impacts of the Safer Cities Initiative, a zero tolerance policy program initiated by the city of Los Angeles in 2006. Drawing on the 'broken-window theory', the program's official policy was meant to secure the streets and its primary goal was to firmly condemn misdemeanors. Camping was deemed illegal and homeless people were banned from the streets, jeopardizing civil liberties and questioning the right to be different. Drawing on first-hand interviews and reports, this article shows that this type of program represents a discriminatory and ineffective approach to poverty. It not only fails to fight serious and violent crimes, but also reinforces the processes through which neoliberalism exacerbates social differences and criminalizes poverty.

Les politiques néolibérales transforment l'appréhension des espaces publics. Les municipalités qui souhaitent redorer leur image pour attirer de nouveaux capitaux, s'emploient à se débarrasser des "indésirables " (les sans-abris et autres personnes perçues comme des nuisances) qui ternissent l'image de leurs espaces publics. Cet article explore les effets sociopolitiques de Safer Cities Initiative (Initiative pour des villes plus sûres), un programme de « tolérance zéro » mis en place par la municipalité de Los Angeles en 2006. En s'appuyant sur la théorie dite de la " vitre brisée ", la politique officielle vise à sécuriser la rue, en condamnant des infractions mineures avec fermeté. Camper est devenu illégal et les sans-abris ont été exclus de la rue, remettant en cause les libertés publiques ainsi que le droit à la différence. En s'appuyant sur des entretiens de première main et des rapports, cet article montre en quoi ce type de programme représente une approche de la pauvreté à la fois discriminante et inefficace. Ce programme est ne parvient non seulement pas à enrayer la criminalité la plus grave mais il renforce également les processus au moyen desquels le néolibéralisme exacerbe les différences sociales et criminalise la pauvreté. 


\section{INDEX}

Mots-clés: néolibéralisme, espaces publics, sans-abris, libertés publiques, Los Angeles, politiques urbaines, États-Unis

Keywords: neoliberalism, homelessness, civil liberties, public space, Los Angeles, United States, urban policies

\section{AUTHOR}

\section{MARINE DASSÉ}

Dr Marine Dassé holds a PhD in American studies. She currently teaches at the University of French Polynesia and is a member of the research team Gouvernance et Développement Insulaire. Her research deals with the urban and social impacts of neoliberalism in Southern California. Her other research interests include anti-consumerist movements and alternatives to global capitalism. Contact: mdasse[at]parisnanterre.fr 